Available Online at https://journal.unismuh.ac.id/index.php/otoritas

Otoritas : Jurnal Ilmu Pemerintahan, 10 (1), April 2020, 24-42

\title{
Implementing Ethical Recruitment of Migrant Workers: Evidence from the Palm Oil Sector in Malaysia
}

\author{
Andika Wahab*j \\ Institute of Malaysian and International Studies, The National University of Malaysia, Lingkungan \\ Johan, 43600 Bangi, Selangor, Malaysia.
}

Received: 27 December 2019; Revised: 24 March 2020; Accepted: 11 April 2020

\begin{abstract}
Growing allegation of irregularities in the conduct of migrant workers' recruitment drives global effort to eliminate unethical practices in the migration industry. As part of the international value chain, palm oil companies in Malaysia are expected to implement ethical recruitment practices. This study is an attempt to assess the employers' commitment and practices in implementing ethical recruitment in Malaysia. Deriving from four palm oil mills (employers) and further validated through a survey conducted against 92 Nepalese workers - this study argues that while employers have committed to cover certain costs of their migrant workers' recruitment, they lack a clear policy commitment, due diligence and monitoring against the labour recruiters. Consequently, the labour recruiters (including the intermediaries) mainly in Nepal have imposed another set of recruitment costs which already covered by the employers in Malaysia. Alarmingly, the Nepalese workers have paid even a higher cost of recruitment than the cost borne by the employers. For ethical recruitment to be effectively implemented, the employers' monetary commitment to cover the cost of their workers' recruitment must be complemented with efforts to engage and monitor the conduct of the labour recruiters in migrant workers' origin country.
\end{abstract}

Keywords: Ethical Recruitment; Migrant Workers; Palm Oil; Human Rights; Labour Rights

How to Cite: Wahab, A. (2020). Implementing Ethical Recruitment of Migrant Workers: Evidence from the Palm Oil Sector in Malaysia. Otoritas : Jurnal Ilmu Pemerintahan, 10(1), 24-42.

Permalink/DOI: https://doi.org/10.26618/ojip.v10i1.2931

${ }^{*}$ Corresponding Author.

E-Mail : andikawahab@ukm.edu.my

Copyright (C) 2020, Otoritas : Jurnal Ilmu Pemerintahan, ISSN: 2088-3706 (Print), ISSN: 2502-9320 (Online) 
Available Online at https://journal.unismuh.ac.id/index.php/otoritas

Otoritas : Jurnal Ilmu Pemerintahan, 10 (1), April 2020, 25

\section{INTRODUCTION}

International migration serves as an effective poverty reduction tool for millions of migrant workers through overseas employment and sending of remittance to their origin country (Wickramasekara, 2000). It also serves as an essential factor to maintain or enhance productivity and reduce the cost of operation in various sectors of the economy in receiving countries (Carpio et al., 2015).

Individuals from underdeveloped and developing countries tend to look abroad for better life opportunities. Evidence reveals that many factors drive people's migration such as poverty, poor living standards and the lack of decent work, and humanitarian conflicts and natural disasters in many source countries (Black et al., 2011; International Labour Organization, 2016). A survey conducted by the ILO (2016) also uncovers that the willingness to migrate is widespread, and acute, particularly among the youth between 15 and 24 years old.

While international migration can benefit the workers on many aspects (e.g., employment, remittance and social mobility), their negative consequences cannot be glossed over. Scholars warn that mistreatment and labour-related exploitation against migrant workers in many receiving countries are on the rise (Auwal, 2010; Crinis, 2010; Kaur, 2010; Benach et al., 2011; Ducanes, 2013; Jureidini, 2016; Spaan \& Naerssen, 2018).

A growing number of studies and public reports uncovering various forms of labour exploitation such as withholding of passports and other identity documents (Fair Labor Association \& Consumer Good Forum, 2018; Earthworm Foundation, 2019; Wahab, 2019); employing children to undertake hazardous activities and harmful to their child development (Jomo et al. 1992; Ismail, 2008; Rahimah \& Suriati, 2013; Dzurizah \& Jalihah, 2014); non-payment of wages and other practices that restrict workers' freedom of movement and their right to association and collective bargaining (Kanapathy, 2008; Auwal, 2010; Abdul Rashid, 2010; Kaur, 2014; Dannecker, 2005; Mei Wei \& Yazdanifard, 2015; Norhidayu et al., 2016; Azad, 2018).

Others argue that many migrant workers are recruited through a complex recruitment process in origin country involving layers of labour agents, brokers, middle person and social networks where workers are often unaware of the risks and consequences they would face (Kanapathy, 2008; Rahman, 2012; Azad, 2018). The complex nature of their recruitment process has many negative consequences, one of which is the multiplication of recruitment costs borne by the workers and the potential case of bonded labour (Kanapathy, 2008; Jureidini, 2016).

In many instances, irresponsible practices and manipulation during the recruitment process leading to the high cost of migration imposed towards migrant workers (Kanapathy, 2008; Azad, 2018). This subsequently situates the workers at risk of many forms of other labour exploitation upon arrival in the destination country, including in debt bondage slavery-alike situations, as well as working in excessive hours to repay their cost of migration.

The growing allegations and actual cases of unethical recruitment practices committed against migrant workers have prompted global actions to address it. This includes the most recent effort made by the ILO in 2019 through the adoption of the ILO's General Principles and Operational Guidelines for Fair Recruitment. Part 1(III)(1) of the ILO's general principles advocate that the recruitment of workers should respect, protect and fulfil the internationally-recognized human rights, including the prohibition of forced and child labour, right to association and collective bargaining, as well as non- 
discrimination in respect of employment and occupation (ILO, 2019). Recruitment should also take into account policies and practices that promote efficiency, transparency and protection for workers (see Part 1(III)(4)). The ILO's guiding principles make it explicit that no recruitment fees or related costs should be charged to, or otherwise borne by, workers or jobseekers (see Part 1(III)(7)).

Generally, there is no standard definition describing what constitute ethical recruitment practices. However, in the private sector, the term has been broadly referred to companies' and intermediaries' practices that do not charge recruitment fees to migrant workers (Open Working Group on Labour Migration and Recruitment, 2017). A consortium of multinational companies and expert organizations known as the Leadership Group for Responsible Business demands multinational corporations to implement ethical recruitment by adopting the Employer Pay Principles (EPP) - a principle that guarantees no worker should pay for a job, and any cost of recruitment should be borne by the employer.

While the cost of migration (or recruitment fee) has been widely used as a yardstick to define whether a recruitment practice is ethical or otherwise, there are other aspects of recruitment needing thoughtful consideration. This includes the employers' understanding of what ethical recruitment means in their human resource management. Secondly, employers' policy expression and practices relating to the recruitment of migrant workers, such as, whether the employer has a clear policy commitment that governs ethical recruitment practice; or whether the company has due diligence in place to regularly monitor the conduct of recruitment among their labour recruitment agencies?

In Malaysia, selected sectors of the economy such as manufacturing, agriculture and plantation remain as export- oriented and labour-intensive industry (Kaur, 2010; Mohamed et al., 2012; Moktari et al., 2017). These sectors rely heavily on low-paid and unskilled migrant workers to fill up companies' labour requirement (Dannecker, 2005; Crinis, 2010; Azman, 2013; Mei Mei \& Yazdanifard, 2015).

Malaysia's Ministry of Human Resources in 2017 (New Straits Times, 2017) estimated that there were a total of 1.8 million migrant workers registered in Malaysia, originating mainly from Indonesia (39 per cent), Nepal (21.3 per cent), Bangladesh (14.9 per cent), India (6.3 per cent) and Myanmar ( 6 per cent). Other migrant workers, collectively form about 12.5 per cent are originating from Pakistan, Philippines, Viet Nam, China, Thailand, Sri Lanka, Cambodia and Lao PDR.

Malaysia signed a total of nine memoranda of agreements (MoU) with source countries, including Bangladesh and Indonesia. Recently, in September 2019, an MoU signed by the Governments of Malaysia and Nepal, after a series of negotiations between both sides - in an attempt to strengthen the protection of the Nepalese workers, including making the employers covering the recruitment cost of their Nepalese workers into Malaysia (Anon, 2018).

The palm oil sector in Malaysia consists of plantations, mills and refineries. They contribute to Malaysia's annual export revenue between RM60 billion (approximately US\$15 billion) and RM70 billion (US\$ 17.5 billion) (Azman, 2013). The growing demand for palm oil-related products and the expansion of palm oil business operations in Malaysia necessitate labourers, particularly unskilled migrant workers to fill up labour requirement on sites. It is estimated that more than a half-million of workers - the majority of which are migrant workers from Nepal, Bangladesh and Indonesia are hired in the palm oil plantations, mills and refineries throughout Malaysia (Azman, 
2013).

Allegations of various forms of labour exploitation in Malaysia, including in the palm oil sector have been continuously highlighted not only in academic researches (Dannecker, 2005; Abdul Rashid, 2010; Mohd Na'eim et al., 2014; Mei Wei \& Yazdanifard, 2015; Varkkey, 2015; Norhidayu et al., 2016; Jasni \& Othman, 2017; Azad, 2018; Wahab, 2019) but in international organizations' reports (Finnwatch, 2014; Amnesty International, 2016), and media's exposures (Wall Street Journal, 2015).

As part of the global value chains, palm oil companies in Malaysia are also expected to implement ethical recruitment practices. This commitment is often linked to their collective pledge to prevent and address the incidence of forced and bonded labour in the palm oil sector. Given the previous allegations of labour exploitation of migrant workers in the palm oil sector in Malaysia, coupled with the complex process of their recruitment - this study aims to assess the implementation of recruitment practices in the palm oil sector in Malaysia. Specifically, this study seeks to respond to these three research inquiries; (i) how do palm oil companies (employers) understand ethical recruitment? (ii) how do palm oil companies practice recruitment of migrant workers; (iii) do employers pay the cost of recruitment of their migrant workers.

This study focuses specifically among the palm oil mills, referred hereinafter and interchangeably as "employers" and "companies", and their respective Nepalese migrant workers. This study involves four employers located in three States in Peninsular Malaysia, namely, Johor, Pahang and Negeri Sembilan. For the purpose of this study, ethical recruitment is broadly referred to as a recruitment process that respects, protects and fulfils the internationally-recognized human rights, as stipulated by the ILO's general principles, under Part 1(III)(1).
This study aims to enrich the growing literature in the migration industry (MI) research. Currently, scholars from various fields such as sociology, anthropology, political sciences and the economics attempt to explain how MI (as an industry) fosters, assists and constraints migration (Glick-Schiller, 2009; Spaan \& Hillmann, 2013; Cranston, 2016; Cranston, Schapendonk \& Spaan, 2018). The MI aims to shape mobility pattern through the services they offer, from how a migrant decides his/her decision to migrate, and after he/she has arrived at a destination country.

While the current MI researches have been able to provide a scholarly explanation on the dynamic role of manpower agencies and intermediaries in promoting and facilitating migration, there is a lack of emphasis on the part of employers. This study aims specifically to fill the knowledge gaps by linking the employers' recruitment practices and migration process of migrant workers. By focusing specifically on the migration of Nepalese workers to Malaysia, this study also contributes in elevating the existing studies relate to migration corridor approach - that is between a pair of a source country (Nepal) and a destination country (Malaysia) (Spaan \& Naerssen, 2018).

\section{RESEARCH METHODS}

As explained previously, this study focuses specifically on assessing the implementation of recruitment practices among palm oil mills (employers) and their respective Nepalese migrant workers. In doing that, this study used four methods of data collection, namely: (i) a key informant interview; (ii) a survey; (iii) a semi-structured interview; and (iv) a documentation review and field observation. The use of these combined methods has benefited this study on several aspects. First, it assisted this study to differentiate between the costs borne by employers and workers, respectively. Sec- 
ondly, it enabled this study to capture and relate the diversity of views from different segments of the key informants and respondents and validate them through case studies and quotes from the informants. Thirdly, by triangulating information from various sources of information, it further strengthened the credibility of the research findings and reduced biases.

Concerning the first method of data collection, this study conducted four sessions of key informant interview with four employers (mills). The four employers are referred to as the key informants ("mill1"), ("mill2"), ("mill3") and ("mill4") in this study. All employers were represented by their respective management employees at the middle-management level (e.g., manager and assistant manager).

This study surveyed a total of 92 Nepalese workers those employed in all four companies. The surveyed Nepalese workers were selected using a random sampling strategy. Initially, the employers provided a list of all migrant workers working in each of the companies. The workers were then selected based on several basic criteria. These include; (i) the workers' nationality (must be a Nepalese worker); (ii) working with the company not more than three years; (iii) workers must have their valid passport and working pass renewed.

Each survey session took about 30 minutes or less at a place convenient to the worker and without the presence of their superior or company's representative. While the survey session was conducted privately (without the presence of the employer), the Nepalese respondents were still cautious in answering the survey questions, afraid of the potential repercussion against themselves. This serves as a limitation in this study.

The third method of data collection is a semi-structured interview with a total of 22 Nepalese workers. The 22 Nepalese workers (hereinafter referred to as the
"Nepalese informants") were among those 92 Nepalese workers who were initially surveyed for this study. Only a selected few of informants' responses, where relevant, are used in this study.

The last method of data collection is a documentation review and field observation. This method has enabled this study to validate information received from the employers and the Nepalese workers. This method involved a review of relevant internal documents of the companies such as workers' employment contract, monthly payroll, recruitment invoices and key companies' policies (e.g., employment policy, social policy, sustainability policy, and safety and health policy).

The data collection was undertaken for a period of eight months, beginning September 2018 until May 2019 in Peninsular Malaysia. In the conduct of data collection, the following principles were applied, namely; (i) the respect of confidentiality. For instance, all informants and respondents were informed that their name and affiliation, including the name of the company, will be not revealed in this study; (ii) getting consent from the key informants and respondents prior to any of the data collection was conducted, and the future use of their personal stories and information. All respondents have signed a consent agreement prior to the survey and interview sessions conducted; and (iii) ensuring the privacy of the data collection process. For example, all survey and semi-structured interview sessions were conducted in a private room, without the presence of their respective employer.

For security reasons and to prevent any unintended consequences, the personal details of the Nepalese respondents and informants have been kept confidential. As such, the names of respondents and informants shown in this study are not their real personal information. 


\section{RESULTS AND DISCUSSION}

How Do Companies understand Ethical Recruitment?

This sub-section aims to respond to the first research inquiry explained earlier in this study, namely, how the companies understand ethical recruitment? This study found that all employers are unaware of the meaning of ethical recruitment and the expected standards to implement it. It was the first time that they (all mills) heard about ethical recruitment, during which the data collection was conducted.

However, key informants (mill1) and (mill3) stressed the point that it is already a common practice among the palm oil mills in Malaysia to cover the cost of recruitment of their migrant workers. A key informant (mill1) informed that his company has already borne the essential recruitment items such as levy fee, a one-way airfare ticket and recruitment fee to labour recruiter in Malaysia. He then questioned the need to put in place another set of ethical recruitment standards as the majority of the palm oil companies in Malaysia have already implemented the practice of covering the recruitment costs of their migrant workers for many years.

The key informant (mill3) argued that it is the responsibility of the migrant workers to cover the other costs of recruitment in origin countries such as the costs paid to labour agents and intermediaries, as well as the cost to make their travel documents such as passport and working pass. Besides, he added that his company (mill3) was only required by the Malaysian labour law to cover the recruitment costs such as levy and recruitment fees in Malaysia. There is no necessity to cover the recruitment costs, if any, in the origin country of their migrant workers, he added.

Based on responses expressed by the key informants, this study found that there is a lack of understanding of the overarching principles of ethical recruitment. For example, while the employers have committed to pay certain costs of their migrant workers' recruitment, this inadequately reflects the expected commitment of companies in covering the cost of recruitment of their workers. There are other costs of recruitment items such as the processing fees of migrant workers' travel documents, expenses related to training and medical checkup in origin country should also be borne by the employers.

Besides, ethical recruitment does not only refer to companies' responsibility in covering the cost of migration of their migrant workers. It should also include companies' responsibility to put in place a clear policy that expresses its commitment to execute ethical recruitment; developing a due diligence process; providing pre-departure training; and other practices that fulfil the enjoyment of human rights of their workers. These will be discussed in the next section.

How Do Companies Recruit their Migrant Workers?

This sub-section responds to the second research inquiry that is: how companies practice recruitment of their migrant workers? First and foremost, this sub-section looks at companies' commitment in the form of policy expression that governs their recruitment practices. When asked about a written policy commitment to managing migrant workers, all employers (except mill4) reported that they have at least a general employment policy covering both local and migrant workers in their own operations (see Table 1). After reviewing their policy documents (except mill4), where available, this study found that there is no concrete policy expression governing recruitment practices.

Similarly, none of the employers had put in place a reimbursement initiative in 
order to repay the recruitment costs paid by their Nepalese workers in Nepal. A key informant (mill2) emphasized that there is no necessity for his company to create the reimbursement plan, not until the company has made a clear commitment to repay the recruitment costs paid by the workers.

Another key informant (mill3) added that it is rather difficult for the company to reimburse the recruitment costs paid by the workers in Nepal. This is because he claimed that workers often do not keep a record of their spending during the recruitment process. His company cannot repay the workers based on what they claim without receipts or any form of evidence. Besides, the company has no clue of which recruitment items in origin country the company should repay.

While all employers practised direct employment (i.e., all migrant workers are directly hired and paid by the employers), they used a third party - that is the labour recruiters in Malaysia to source migrant workers from Nepal. There is no clear and fixed selection criterion has been used to choose the services provided by the labour recruiters. However, one employer (mill1) reported that the registration status of the recruiter is crucial. He further informed that their (labour recruiters) good track record and reasonable service fee - are the other factors attracting the employers to keep using their recruitment services.

A key informant (mill1) informed that his company has been using the same labour recruiter in Malaysia for the past 15 years. He further clarified that the services provided by the labour recruiter have been very instrumental in ensuring adequate workers are supplied to his company. The labour recruiter is a registered entity under the Private Employment Agencies Act in Malaysia and has been able to demonstrate good performance and charging a reasonable recruitment fee.
Despite the good impression about the services provided by the labour recruiters in Malaysia, none of the employers had conducted regular due diligence to monitor the conduct of their labour recruiters during the recruitment process. When asked whether their respective labour recruiters have a relevant standard operating procedure in recruiting migrant workers, none of the employers was aware of this. All employers also indicated that they were not aware of the labour recruiters and other intermediaries involved in recruiting the migrant workers in Nepal. A key informant (mill1) stressed that it is the responsibility of their labour recruiter in Malaysia to be aware of all these details, not his company.

The conduct of a post-arrival programme not only aims to set the tone for the employer-worker relationship but to also serve as a platform to listen and respond on issues facing the newly-arrived workers with respect to their recruitment process. While three employers (mill1, mill2 and mill4) have conducted a regular post-arrival training and orientation, none of them has conducted due diligence or any form of risk assessment on the recruitment process of their newly-arrived workers.

A key informant (mill2), informed that all workers in his company, including the newly-arrived Nepalese workers, will have access to the company's grievance mechanism. If the workers have issues with regard to their recruitment process, they can always use the complaint log book or raise it to their respective supervisors, he added. He further noted that for the past five years, there is no case has been lodged using the company's grievance log book with regards to their recruitment process. Most cases reported to the company's grievance record are issues related to overtime pay, accommodation-related matters and other social problems such as alcohol use disorder.

Upon arrival at the workplace, all 
migrant workers, including the Nepalese in all four companies are required to hand over their passports to the management body for safekeeping. The workers will be asked to sign a consent letter, permitting the management body to keep their passport. The workers will need to inform the management body, at least one working day, prior to accessing their respective passport, mainly for personal use such as visiting friends outside the locality.

A key informant (mill3) emphasized that it is a common practice for companies in Malaysia to keep the migrant workers' travel document, including passport for safe-keeping. He stressed that this practice is maintained for the best interest of the workers. When asked whether such practice is permissible by the law, the key informant (mill3) informed that all migrant workers had given their consent for the company to keep their passport, and that is aligned with the Malaysian Passport Act 1966. A key informant (mill2) informed that some workers are allowed to keep their own passport. However, this only applies to senior Nepalese workers those work more than five years with his company.

The next sub-section will respond to the second research inquiry, namely, do employers pay the cost of recruitment of their migrant workers.

Who Pay the Cost of Recruitment?

As claimed earlier by the key informants, all employers have already committed to paying certain costs of their Nepalese workers' recruitment to Malaysia. This study found that the average recruitment cost borne by the employers to recruit one Nepalese worker is US\$ 1,130 . This average recruitment cost is divided into two categories. First, the recruitment cost during the pre-departure stage that is US\$ 970 (86\%) for each Nepalese worker recruited; second, the recruitment cost during the post-arrival phase that is US\$160 (14\%) per worker. At individual company's level, mill3 covered the lowest cost of recruitment for each Nepalese worker that is US\$980, while mill4 borne the highest amount of recruitment cost that is US\$ 1,310 (further see Table 2).

While this study is able to provide the cumulative (estimated) recruitment cost borne by each company (and divided by the recruitment phases), it is unable to provide the breakdown of the cost of recruitment. This is partly because the management body of the employers did not keep a good record of their recruitment spending. While invoices issued by the labour recruiters were available, they did not indicate a clear amount of recruitment cost per individual Nepalese worker recruited. Additionally, the invoices did not breakdown the cost by recruitment items (i.e., how much is the airfare cost, or medical and insurance expenditures?). Invoices often issued in a bulk amount or only indicate the total cost of recruitment.

The key informant (mill3) acknowledged the difficulty to breakdown the recruitment cost by recruitment items such as visa fee, working pass fees, training and medical expenditures, just to mention a few. He claimed that the recruitment invoices issued by the labour recruiter are based on a group of people being recruited for a particular time of recruitment. Besides, he further informed that the actual cost of recruitment per one migrant worker is not fixed, and it changes depending on how many workers (collectively) to be recruited and the period of recruitment.

Table 3 shows the recruitment cost by items - both at the pre-departure and post-arrival stages borne by the employers. Though all employers were unable to provide the breakdown of the recruitment cost (by recruitment items), all employers were fully aware of what they are paying for. In other words, the employers were aware of each recruitment item covered in the recruitment package. These include a service fee to labour recruiter; 
Available Online at https://journal.unismuh.ac.id/index.php/otoritas

Otoritas : Jurnal Ilmu Pemerintahan, 10 (1), April 2020, 32

Table 1. Employers' Practices with respect to Recruitment of Migrant Workers Source: Fieldwork in Peninsular Malaysia (2018 \& 2019)

\begin{tabular}{|c|c|c|c|c|}
\hline \multirow[t]{2}{*}{ Companies' Practices } & \multicolumn{4}{|c|}{ Employers } \\
\hline & Mill(1) & Mill(2) & Mill(3) & Mill(4) \\
\hline $\begin{array}{l}\text { Availability of a written policy relat- } \\
\text { ed to migrant workers (e.g., em- } \\
\text { ployment policy) }\end{array}$ & / & / & / & $\mathrm{X}$ \\
\hline $\begin{array}{l}\text { Availability of a specific policy on } \\
\text { workers' recruitment aligned with } \\
\text { the broad definition of ethical re- } \\
\text { cruitment. }\end{array}$ & $\mathrm{X}$ & $\mathrm{X}$ & $\mathrm{X}$ & $\mathrm{X}$ \\
\hline $\begin{array}{l}\text { Availability of reimbursement initi- } \\
\text { ative to repay the cost of recruit- } \\
\text { ment borne by the workers }\end{array}$ & $\mathrm{X}$ & $\mathrm{X}$ & $\mathrm{X}$ & $\mathrm{X}$ \\
\hline $\begin{array}{l}\text { Conduct of due diligence against } \\
\text { labour recruiters in Malaysia and } \\
\text { Nepal }\end{array}$ & $\mathrm{X}$ & $\mathrm{X}$ & $\mathrm{X}$ & $\mathrm{X}$ \\
\hline $\begin{array}{l}\text { Post-arrival training and/or regular } \\
\text { orientation provided to the newly- } \\
\text { arrived workers }\end{array}$ & / & / & $\mathrm{X}$ & / \\
\hline $\begin{array}{l}\text { Post-arrival due diligence or risk } \\
\text { assessment against workers upon } \\
\text { arrival in Malaysia }\end{array}$ & $\mathrm{X}$ & $\mathrm{X}$ & $\mathrm{X}$ & $\mathrm{X}$ \\
\hline $\begin{array}{l}\text { Provision or establishment of an } \\
\text { internal grievance mechanism }\end{array}$ & / & / & / & $\mathrm{X}$ \\
\hline $\begin{array}{l}\text { Withhold workers' passport and } \\
\text { other travel documents (i.e., immi- } \\
\text { gration card) }\end{array}$ & / & / & / & / \\
\hline
\end{tabular}

Table 2. Cost of Recruitment (Estimated) Borne by the Employers Source: Fieldwork in Peninsular Malaysia (2018 \& 2019)

\begin{tabular}{|c|c|c|c|}
\hline \multirow[t]{2}{*}{$\begin{array}{c}\text { Employer } \\
\text { (Respondents) }\end{array}$} & \multicolumn{3}{|c|}{$\begin{array}{c}\text { Average recruitment Cost (estimated) Borne by Employers } \\
\text { (in US\$) for Each Nepalese Migrant worker, } \\
\text { Categorized by Recruitment Phase }\end{array}$} \\
\hline & Pre-Departure Phase & $\begin{array}{c}\text { Post-Arrival } \\
\text { Phase }\end{array}$ & Total Cost \\
\hline Mill 1 & US\$ 970 & US\$ 180 & US\$ 1,150 \\
\hline Mill 2 & US\$ 940 & US\$ 140 & US\$ 1,080 \\
\hline Mill 3 & US\$ 910 & US\$ 70 & US\$ 980 \\
\hline Mill 4 & US\$ 1,060 & US $\$ 250$ & US\$ 1,310 \\
\hline $\begin{array}{l}\text { Average Cost (all } \\
\text { mills) }\end{array}$ & $\begin{array}{c}\text { US\$970 } \\
(86 \%)\end{array}$ & $\begin{array}{c}\text { US } \$ 160 \\
(14 \%)\end{array}$ & $\begin{array}{c}\text { US } \$ 1,130 \\
(100 \%)\end{array}$ \\
\hline
\end{tabular}


levy, visa and working permit fees; security bond; medical check-up and insurance cost; and the airfare cost - all of which are the recruitment items at the predeparture stage. At the post-arrival stage (in Malaysia), it is common for the employers to cover the costs of the workers' medical check-up; transportation cost (mill1), as well as training and inductionrelated costs.

While all employers have proven that they have committed to pay certain costs of their Nepalese workers' recruitment, the workers themselves have paid a certain amount of recruitment cost. Based on a sample of 92 Nepalese workers in four mills, this study found that each Nepalese worker paid (on average) US\$1,660 to be recruited to Malaysia (see Table 3). This suggests that the workers are paying more than the employers have covered with an average difference of US\$ 530 .

The recruitment cost paid by the Nepalese workers often includes recruitment items such as the service fee to labour agent (may consist of local agents and other intermediaries in Nepal); visa and working pass fees; a fee to make their travel document; a fee for medical checkup and insurance; and a fee for air flight ticket - all of which are the costs paid at the pre-departure stage. This study found no recruitment items were paid by the workers at the post-arrival stage, in Malaysia.

A Nepalese informant (1) reported that the employer usually bears the recruitment cost in the post-arrival stage in Malaysia. These include the cost for road transportation from the airport (i.e., Kuala Lumpur International Airport - KLIA) to his workplace in Johor; meals and accommodation during the induction programme; cost for another medical checkup in Malaysia.

Another Nepalese informant (2) informed that:

"When I arrived in Malaysia, my employer picked me up at the airport (he may refer it to the KLIA), and immediately sent me to this mill in Johor. My employer didn't charge or deduct my salary for this transportation service".

As the Nepalese workers claimed that they too had paid a certain amount of recruitment cost during their recruitment process, this study looks closely at the recruitment items in which both the workers and the employers have covered. Interestingly, more than half of the recruitment items paid by employers in Malaysia were also paid by the Nepalese workers in Nepal. These recruitment items include fees for visa, working pass; medical check -up in Nepal; insurance coverage in Nepal; and airfare cost.

Charging workers for recruitment items which had already been covered by the employers in Malaysia depicts malpractices by the labour recruiters and the intermediaries in Nepal. This was made possible given the lack of awareness among the workers on what costs had already been paid by their respective employer.

A Nepalese informant (3) informed that he was unaware that his employer had already paid the recruitment cost in Malaysia. He said, when he was approached by the intermediary in his village in Nepal, he was told to pay a total amount of recruitment cost to cover his working pass, levy, insurance and the airfare ticket.

Another Nepalese informant shared that:

"The agent didn't tell us that the employer in Malaysia had paid our recruitment cost. For us, getting a job is important, and we only want to know how much our salary in Malaysia. Because we were so desperate to get a job, we just listened and adhered to the agent in Nepal. Further, we trusted the agent because they are from our own community".

A similar impression was shared by another Nepalese informant (5):

"I had been unemployed for many 
Available Online at https://journal.unismuh.ac.id/index.php/otoritas

Otoritas : Jurnal Ilmu Pemerintahan, 10 (1), April 2020, 34

Table 3. Cost of Recruitment: Comparison between the Costs Borne by the Employers and the Nepalese Workers

Source: Fieldwork in Peninsular Malaysia (2018 \& 2019)

\begin{tabular}{|c|c|c|c|c|c|c|c|c|}
\hline \multirow{2}{*}{$\begin{array}{l}\text { Recruitment Items } \\
\text { covered by work- } \\
\text { ers and employers }\end{array}$} & \multicolumn{2}{|c|}{ Mill (1) } & \multicolumn{2}{|c|}{ Mill (2) } & \multicolumn{2}{|c|}{ Mill (3) } & \multicolumn{2}{|c|}{ Mill (4) } \\
\hline & Workers & Employer & Workers & Employer & Workers & Employer & Workers & Employers \\
\hline \multicolumn{9}{|c|}{ Pre-departure stage (in Nepal) } \\
\hline $\begin{array}{l}\text { Service fee for la- } \\
\text { bour agent / middle } \\
\text { person }\end{array}$ & / & / & / & / & / & / & / & / \\
\hline Levy fee & $\mathrm{x}$ & / & $\mathrm{x}$ & / & $\mathrm{x}$ & / & $\mathrm{x}$ & / \\
\hline Visa fee & / & / & / & / & / & / & / & / \\
\hline Work permit fee & / & / & / & / & / & / & / & / \\
\hline $\begin{array}{l}\text { Making identity } \\
\text { card and passport } \\
\text { (fee) }\end{array}$ & / & $\mathrm{x}$ & / & $\mathrm{x}$ & / & $\mathrm{x}$ & / & $\mathrm{x}$ \\
\hline Security bond & $\mathrm{x}$ & / & $\mathrm{x}$ & / & $\mathrm{x}$ & / & $\mathrm{x}$ & / \\
\hline $\begin{array}{l}\text { Medical check-up } \\
\text { fee (home country) }\end{array}$ & / & / & / & / & / & / & / & / \\
\hline $\begin{array}{l}\text { Insurance fee } \\
\text { (home country) }\end{array}$ & / & / & / & / & / & / & / & / \\
\hline $\begin{array}{l}\text { Training / orienta- } \\
\text { tion cost in home } \\
\text { country }\end{array}$ & $\mathrm{x}$ & $\mathrm{x}$ & $\mathrm{x}$ & $\mathrm{x}$ & $\mathrm{x}$ & $\mathrm{x}$ & $\mathrm{x}$ & $\mathrm{x}$ \\
\hline $\begin{array}{l}\text { Additional } \\
\text { cessing fee (no } \\
\text { further explana- } \\
\text { tion) }\end{array}$ & $\mathrm{x}$ & / & $\mathrm{x}$ & $\mathrm{x}$ & $\mathrm{x}$ & $\mathrm{x}$ & $\mathrm{x}$ & / \\
\hline $\begin{array}{l}\text { Airfare cost (one- } \\
\text { way ticket) }\end{array}$ & / & / & / & / & / & / & / & / \\
\hline \multicolumn{9}{|c|}{ Post-arrival stage (in Malaysia) } \\
\hline $\begin{array}{l}\text { Medical check-up } \\
\text { fee in Malaysia }\end{array}$ & $\mathrm{x}$ & / & $\mathrm{x}$ & / & $\mathrm{x}$ & / & $\mathrm{x}$ & / \\
\hline $\begin{array}{l}\text { Land transportation } \\
\text { in Malaysia }\end{array}$ & $\mathrm{x}$ & / & $\mathrm{x}$ & $\mathrm{x}$ & $\mathrm{x}$ & $\mathrm{x}$ & $\mathrm{x}$ & $\mathrm{x}$ \\
\hline $\begin{array}{l}\text { Training / induc- } \\
\text { tion cost in Malay- } \\
\text { sia }\end{array}$ & $\mathrm{x}$ & / & $\mathrm{x}$ & / & $\mathrm{x}$ & / & $\mathrm{x}$ & / \\
\hline Average recruit- & US\$ & US\$ & US\$ & US\$ & US\$ & US\$ & US\$ & US\$ \\
\hline $\begin{array}{l}\text { ment cost borne } \\
\text { by the worker and } \\
\text { employer }\end{array}$ & 1,753 & 1,150 & 1,685 & 1,080 & 1,760 & 980 & 1,440 & 1,310 \\
\hline Difference & \multicolumn{2}{|c|}{ US\$ 603} & \multicolumn{2}{|c|}{ US\$ 605} & \multicolumn{2}{|c|}{ US\$ 780} & \multicolumn{2}{|c|}{ US\$ 130} \\
\hline $\begin{array}{c}\text { Avegare differ- } \\
\text { ence }\end{array}$ & \multicolumn{6}{|c|}{ US\$ 530} & & \\
\hline
\end{tabular}


years. When the agent came to my village and told me about the job opportunity in Malaysia, I grabbed it. I was not even briefed about the job scope and the location of my employer in Malaysia. What I was made to aware was that I would be working in an air-conditioned factory in Kuala Lumpur with a monthly salary of US $\$ 500$ (or approximately RM2,000). The agent then asked me to pay the recruitment cost of US $\$ 1,500$ - without telling me what this cost entailed".

A Nepalese informant (6) told that he paid about US\$1,350 to his agent in his township in Nepal. The agent then issued him a receipt, written in English, but the details of the recruitment cost were not stated in the receipt. When asked whether he still keeps the receipt given by his agent in Nepal, the Nepalese informant (6) responded that he misplaced the receipt a long time ago.

When asked whether the employers in Malaysia were aware of the practice of charging the recruitment cost to the Nepalese workers on the side of their labour recruiters in Nepal - none of the companies acknowledged this information. A key informant (mill3) stressed that none of his Nepalese workers complained about the recruitment charges imposed by their labour recruiter or agent in $\mathrm{Ne}$ pal. He claimed that these practices might be associated with the unauthorized intermediaries or individual agents who took advantage by recruiting and channelling the Nepalese workers to the manpower agency (the authorized labour recruiter) those mainly based in Kathmandu, Nepal.

What Went Wrong? Beyond Dollar and Cent

The pledge to implement ethical recruitment goes beyond a financial commitment to cover the recruitment cost of migrant workers from their respective country to the destination country like Malaysia. Instead, it is just one initial step towards committing a responsible recruitment practice in the business sector.

The Institute of Human Rights and Business (IHRB, 2019), for instance, states that while it is strongly expected that employers will bear the full cost of their workers recruitment, such commitment must be clearly expressed in their written policy commitment. Employers are expected to undertake a regular risk assessment on the conduct of their labour recruiters and other business partners, involved directly or indirectly in recruiting migrant workers - both in sending and receiving countries. Employers must also take the necessary action to remedy issues and grievances raised by the workers, including reimbursing the costs paid by workers during their recruitment (Institute of Human Rights and Business, 2019).

Beyond the financial commitment to bear the full cost of recruitment of their migrant workers, this sub-section assesses at what lacking both in terms of other commitment and practices on the side of the employers, and the issues facing the workers during and after their recruitment process.

Firstly, while employers have proven to have covered the certain cost of their Nepalese workers' recruitment such commitment is not reflected in their respective written policy commitment. The existing policy documents such as the Employment Policy, Social Policy and the "No Deforestation, No Peat and Exploitation" (NDPE) Policy of the sample employers do not express their commitment to adhere to the ethical recruitment practice. This shows the absence of accountability and transparency on the side of the employers to roll out this commitment.

The lack of a written policy commitment, especially from the top management hinders any efforts on the ground to act and remedy issues resulting from unethical recruitment practices against the workers. A key informant (mill4) claimed 
that his top management did not issue a direction for the company to reimburse the cost of recruitment which had been paid by their Nepalese Workers in the origin country. Without a clear path from the top management, the human resource department of his company cannot commit to repaying the costs paid by the workers, he added.

The absence of a clear policy commitment also serves as an institutional barrier in implementing a good recruitment practice, particularly on matters concerning the recruitment process and the costs to be paid by the employers to their respective labour agent. This brings me to raise the second point of discussion where all the sample employers have been too reliant on their respective labour recruiters to manage the recruitment process on their behalf.

As claimed by a key informant (mill2), even the cost of recruitment had been determined uncontestedly by the labour recruiter. In other words, there is no bargaining of the recruitment cost, and his employer often in a situation where they will adhere to any cost of recruitment quoted by the labour recruiter. Otherwise, he added, his employer will face a labour shortage, and this will affect the company's productivity.

Employers tend to avoid the hassle in the recruitment process. Of the four sample employers, only one employer (mill2) has a dedicated human resource officer in which his daily task includes, amongst others, managing the recruitment of migrant workers. The other three employers (mill1, mill3 and mill4) do not have a dedicated department and officer in charge of the workforce. All matters concerning the recruitment of workers are placed at either the accounting or procurement department.

Consequently, recruitment processes are often outsourced to the labour recruiters in Malaysia. These include preparing essential documents such as final- izing employment contract, agreement with the manpower agency in the origin country, as well as preparing and submitting documents for the application of migrant workers' quota using the government-dedicated platform.

A key informant (mill3) stated that:

“... we do not have a dedicated human resource officer, that is why we sought assistance from the labour recruiter to draft and finalize employment contract. We determined the salary for the workers and other details such as working hours and working days, but the labour recruiter will help us to ensure these are aligned with the national laws and regulations".

Another key informant (mill4) shared that:

"The procedure to apply migrant workers' quota is a very tedious and complex process. This consumes much time, and the fact that we do not have a dedicated officer to look into these processes we asked the labour recruiter to do it on our behalf. The labour recruiter will make the application, and they charge us based on the services they provide. This practice has been implemented for years, and it is relatively economical compared to having to hire a human resource officer to do it. Furthermore, the recruitment of workers is not a daily routine. We only recruit migrant workers when we need it, usually once a year, depending on the labour turnover in our company".

The risk of committing to unethical recruitment practices is escalating, given the fact that the employers lack a commitment to undertake a regular assessment of the conduct of their labour recruiters. As mentioned earlier, none of the sample employers has any form of risk assessment in place. While the employers have established contact with the respective labour recruiters in Malaysia, they were unaware of the labour recruiters and the intermediaries in Nepal. The employers may lose sight of any irregularities 
throughout the recruitment process in Nepal. The employers also may face the risk of being uninformed and unaware of the risks facing the workers.

While the existing recruitment practice may reduce the companies' operational cost, they may face risks of committing to unethical practices and ultimately will bear the unnecessary costs to remedy any issues deriving from these unethical practices. These include the potential breach of national laws and regulations such as the Anti-Trafficking in Persons and Anti-Smuggling of Migrants (ATIPSOM) act; as well as a contradiction to the existing labour standards which will jeopardize their certification standard especially under the Malaysian Sustainable Palm Oil (MSPO) related to labour standards.

Fourth, it is important to note that the cost of recruitment presented in this study are the estimated figures based on available receipts and invoices shared by the employers, and verbal claims by the workers where physical invoices (or receipts) were not available. The lack of documentation and good record-keeping practices serve as a barrier in moving towards practising ethical recruitment.

For a company to embark on ethical recruitment practices, it must first understand the cost they likely to invest in and compare it with its existing cost for recruitment. The employers need to keep a record of its invoices and receipts paid and issued by the labour recruiter and manage it on an individual basis (per migrant worker) rather than a group of migrant workers. This will help the company to understand the cost of each worker and manage it more systematically.

A key informant (mill2) shared that:

"We do not know how much it costs to recruit one Nepalese worker because the invoices issued by the labour recruiter are often for a group of Nepalese workers sourced to us. The invoices detailed out the costs based on recruitment items such as air flight ticket, working pass and visa (just to mention a few) but not on an individual basis. We also do not have an individual worker's profile in place, except for their monthly payroll. Other documentations such as the copy of the employment contract are placed at our headquarters in the city, not here in operation office".

Likewise, this study also found that the Nepalese workers themselves lack the awareness to keep their receipts and other documentation during the recruitment process. The vast majority of the surveyed Nepalese workers did not keep a copy of their employment contract. When asked whether they remember the key contents of their employment contract such as their scope of work, termination of the contract, etc., only a few of them remembered it.

A Nepalese informant (7) shared the following:

"I did not keep the receipts during our recruitment because we were not asked to do so. Furthermore, why should we keep it unless someone wants to repay us".

Another Nepalese informant (1):

"Our manpower agency (labour agent in Kathmandu) did not give us any receipt during recruitment. I paid the recruitment cost through the individual agent at my village before travelling to Kathmandu. My local agent also did not give me a receipt".

Similar impression raised by other Nepalese informants (8)(9) and (10) that there is no necessity to keep a record of the receipts and other documentation in Nepal, especially during the recruitment process, unless the employers are willing to reimburse the cost of recruitment paid by the workers. Other Nepalese informants (11)(12)(13)and(14) raised another concern that it is almost impossible for them to be provided with receipts for recruitment costs in Nepal such as local transportation (i.e., bus), local accommodation during training and meals. The 
Nepalese informants claimed that these service providers did not issue a receipt.

In brief, it is apparent that the labour recruiters play a very significant role in fostering and facilitating migration of the Nepalese migrant workers to Malaysia. This supports existing pieces of literature of the migration industry (MI) research such as Spaan and Naerssen (2018) - claiming that the Governments of Malaysia and sending countries have given too much space to labour recruiters to mediate the migrant labour market. Consequently, this has resulted in the proliferation of the intermediaries, many of whom are unauthorized individual recruiters, profiting from the desperate migrant workers to work abroad.

This study argues that while irregularities around recruitment practices committed by the labour recruiters and the intermediaries are a concern, the employers have an equally vital role to play. Notably, the employers may prevent the risk of unethical recruitment by, amongst others, ensuring only the authorized labour recruiters involved in recruiting migrant workers, especially in the source country. This needs to be closely monitored, and one way of assessing the conduct of recruitment is through regular due diligence and post-arrival interview session with the workers.

\section{CONCLUSION}

This study concludes that the lack of awareness and understanding hinders the effort to implement ethical recruitment practices, aligned with the ILO's general principles of fair recruitment. While the employers have committed to cover certain costs of their workers' recruitment, they lack a clear policy commitment and due diligence to ensuring the ethical conduct of their respective labour recruiter (s). Consequently, labour recruiters and the intermediaries involved in recruiting workers in Nepal imposed unnecessary recruitment costs which already covered by the employers in Malaysia. Interestingly, this study found that the surveyed Nepalese workers have paid rather a higher cost of recruitment (on average) than the cost borne by the employers. This further strengthens many existing studies on the potential irregularities committed by actors in MI, particularly the labour recruiters and the intermediaries (Spaan \& Hillmann, 2013; Cranston, 2016; Spaan \& Naerssen, 2018).

This is, nevertheless, not to conclude that the employers in Malaysia do not have a responsibility to prevent these unethical recruitment practices. For ethical recruitment to be effectively implemented, this study argues that the employers' monetary commitment to cover the cost of their migrant workers' recruitment must be complemented with a continuous effort to monitor the conduct of their labour recruiters and to implement postarrival due diligence - enabling the newly arrived workers to raise their issues to employers for remediation.

Academically, findings and discussion in this study contribute to enriching the growing scholarly works in labour migration research. Firstly, this study suggests that the concept of ethical recruitment should go beyond employers' monetary commitment. Efforts to raise awareness and exposure among the employers are equally important to ensuring topdown's and bottom-up's buy-in and commitment in implementing ethical recruitment practices. This subsequently paves the way for necessary preventive and remedial actions to be put in place during which the recruitment process is conducted.

Secondly, this study argues that employers have an equally important role in fostering and facilitating recruitment, particularly in the migration industry. Essentially, employers create work opportunity, and that makes it possible for the recruitment process to take place. As such, employers have the market leverage to per- 
suade labour recruiters to provide recruitment services aligned to their (employers) expectations. With a clear policy commitment and guidance to practice ethical recruitment, employers may influence labour recruiters and the intermediaries to ensure ethical conduct of recruitment. This implies the need to consider employers as actors in MI research, along with labour recruiters and the intermediaries.

Thirdly, though this study focuses specifically in the palm oil sector, the findings with respect to employers' understanding, practices and responsibility to cover the cost of their migrant workers' recruitment are relevant for other sectors of the economy. This is because the existing laws and regulations allowing the recruitment of workers by an authorized third party such as labour recruiter in Malaysia, apply to all sectors. Additionally, other economic sectors such as manufacturing and selected services (i.e., international hotel and residency) are subjected to global market demand to implement ethical recruitment practices.

The three points above are preliminary observations, and that would necessitate further scholarly exploration. They may also serve as a source of hypothesis to further investigate the interplay between labour migration, migration industry and labour rights issues occurring in both source and destination countries. Future studies may also be undertaken to investigate and explain the different dynamics facing other nationalities of migrant workers by leveraging a corridor approach between Malaysia (as a destination) and another source country such as Indonesia or Bangladesh.

\section{ACKNOWLEDGEMENT}

The author thanks the National University of Malaysia's (UKM) Research Grant titled "Human Rights Anchored in Business: Practices and Challenges in Malaysia" (00-2019-002) for its support.

\section{REFERENCES}

Abdul Rashid, A.A. (2010). Foreign workers and labour segmentation in Malaysia's construction industry. Construction Management and Economics, 19(8), 789-798. Doi:10.1080/0144619011007202 2

Amnesty International. (2016). The great palm oil scandal: Labour abuses behind big brand names. Retrieved from https:// www.amnesty.org.uk/files/t he_great_palm_oil_scandal_lr.pdf

Anon, A. (2018, October 30). Malaysia, Nepal sealed MoU on migrant workers. Berita Harian. Retrieved from https://www.pressreader.com/ malaysia/berita-harianmalaysia/20181030/28155658682280 7

Anon, A. (2019, September 12). MoU between Nepal and Malaysia on labour supply came into force. Nepal Daily. Retrieved from https:// risingnepaldaily.com/nation/mou -between-nepal-and-malaysia-onlabour-supply-came-into-force

Auwal, M. A. (2010). Ending the exploitation of migrant workers in the Gulf. The Fletcher Forum of World Affairs, 34(2), 87-108.

Azad, A. (2018). Recruitment of migrant workers in Bangladesh: Elements of human trafficking for labour exploitation. Journal of Human Trafficking, 5(2), 130-150.

Azman, I. (2013). The effect of labour shortage in the supply and demand of palm oil in Malaysia. Oil Palm Industry Economic Journal, 13(2), 15-26.

Benach, J., Muntaner, C., Delclos, C., Menendez, M. \& Ronquillo, C. (2011). Migration and "low- 
Available Online at https://journal.unismuh.ac.id/index.php/otoritas

Otoritas : Jurnal Ilmu Pemerintahan, 10 (1), April 2020, 40

skilled" workers in destination countries. PLoS Med, 8(6), 1-4.

Black, R., Kniveton, D., \& Schmidt-Verkerk, K. (2011). Migration and climate change: Towards an integrated assessment of sensitivity. Environment and Planning: Economy and Space, 43(2), 431-450.

Carpio, Del. X., Ozden, C., Testaverde, M., Marouani, M., Nilssond, B. \& Wagnerr, M. (2015). Foreign workers in Malaysia: Labour market and firm level analysis. Malaysian Journal of Economic Studies, 52(1), 1-19.

Cranston, S. (2016). Producing migrant encounter: Learning to be a British expatriate in Singapore through the global mobility industry. Environment and Planning: Society and Space, 34(4), 655671.

Cranston, S., Schapendonk, J., \& Spaan, E. (2018). New directions in exploring the migration industries: Introduction to Special Issue. Journal of Ethnic and Migration Studies, 44(1), 543-557.

Crinis, V. (2010). Sweat or no sweat: Foreign workers in the garment industry in Malaysia. Journal of Contemporary Asia, 40(4), 589-611.

Dannecker, P. (2005). Bangladeshi migrant workers in Malaysia: The construction of the "others" in a multi-ethnic context. Asian Journal of Social Science, 33(2), 246267.

Ducanes, G. (2013). Labour shortages, foreign migrant recruitment and the portability of qualifications in East and South-East Asia. ILO Regional Office for Asia and the Pacific. Retrieved from http:// apmagnet.ilo.org/resources/ labour-shortages-foreign-migrant -recruitment-and-portability-ofqualifications

Dzurizah, I., \& Jalihah, M. S. (2014). Child labour in Sabah (Buruh KanakKanak di Sabah). Kinabalu: University Malaysia Sabah Press.

Earthworm Foundation. (2019). supporting a palm oil mill in Malaysia to return passports to migrant workers. Retrieved from https:// www.earthworm.org/newsstories/changing-passportretention-malaysia-palm-oil

Fair Labor Association and Consumer Goods Forum. (2018). Assessing forced labour risks in the palm oil sector in Indonesia and Malaysia. Retrieved from https:// www.theconsumergoodsforum.co $\mathrm{m} / \mathrm{wp}$ content/ uploads/2018/11/201811-CGFFLA-Palm-Oil-Report-Malaysiaand- Indonesia_web.pdf? utm_source=press\&utm_campaig $\mathrm{n}=$ press

Finnwatch. (2014). The law of the jungle: Corporate responsibility of Finnish palm oil purchases. Retrieved from https:// www.finnwatch.org/ images/ palmoil.pdf

Glick-Schiller, N. C. (2009). Towards a comparative theory of locality in migrations studies: Migrant incorporation and city scale. Journal of Ethnic and Migration Studies, 35 (2), 177-202.

Institute of Human Rights and Business. (2019). Six steps to responsible business. Retrieved from https:// www.ihrb.org/employerpays/ leadership-group-for-responsiblerecruitment

International Labour Organization. (2016). The future of work centenary initiative. ILO's note series 
(No.2). Retrieved from https:// www.ilo.org/wcmsp5/groups/ public/---dgreports/---dcomm/ documents/publication/ wcms_534204.pdf

International Labour Organization (ILO). (2019). General principles and operational guidelines for fair recruitment and definition of recruitment fees and related costs. Retreived from https:// www.ilo.org/global/topics/fairrecruitment/WCMS_536755/lang --en/index.htm

Ismail, A. (2008). Involvement of the Filipino children and economic fishery in Sabah: A moral justice? (Penglibatan dan sumbangan kanak-kanak warga Filipina dan ekonomi perikanan di Sabah: Satu pengadilan moral?) Sosio Humanika, 1(2), 365-390.

Jasni, N., \& Othman, N. (2017). Welfare and the employment issues related to foreign workers in Sabah: A case study of Mensuli estate. Advances in Business Research International Journal, 2(1), 63-77.

Jomo, K. S., Zaini, J., Ramasamy, R., \& Suppiah, S. (1992). Early labour: Children at work on Malaysian plantations. In Jomo, K. S. (Ed.), Child Labour in Malaysia, 144-171. Kuala Lumpur: Forum for Labour Studies Programme, Institute for Advanced Studies, University of Malaya.

Jureidini, R. (2016). Ways forward in recruitment of low-skilled migrant workers in the Asia-States corridor. Published by the International Labour Organization (ILO). Retrieved from https:// www.ilo.org/wcmsp5/groups/ public/---arabstates/---ro-beirut/ documents/publication/ wcms_519913.pdf
Kanapathy, V. (2008). Controlling irregular migration: The Malaysian experience. Published by Regional Office for Asia and the Pacific, International Labour Organization (ILO) (2008, July). Retrieved from https://www.ilo.org/wcmsp5/ groups/public/---asia/---robangkok/documents/ publication/wcms_160587.pdf

Kaur, A. (2010). Labour migration in Southeast Asia: Migration policies, labour exploitation and regulation. Journal of the Asia Pacific Economy, 15(1), 6-19.

Kaur, A. (2014). Managing labour migration in Malaysia: Guest worker programs and the regularization of irregular labour migrants as a policy instrument. Asian Studies Review, 38(3), 345-366.

Mei Wei, W., \& Yazdanifard, R. (2015). The Review of challenges foreign workers face in construction industry of Malaysia. Global Journal of Management and Business Research, 15(4), 13-16.

Mohamed, R. K., Ramendran, C., \& Yacob, P. (2012). The impact of employment of foreign workers: Local employability and trade union roles in Malaysia. International Journal of Academic Research in Business and Social Sciences, 2 (10), 530-541.

Mohd Na'eim, A., Mohamad, F. K., Zaheruddin, O., \& Md. Shukri, S. I. (2014). The dilemma of managing foreign workers in Malaysia: Opportunities and challenges. Global Journal of Human Social Sciences, 14(4), 43-53.

Moktari, A. Y., Murtaza, M., Kassim, M., Illzam, E. M., \& Sharifa, A. M. (2017). Malaysia a favourite destination for immigration in Southeast Asia. 
Journal of Dental and Medical Sciences, 16(8), 84-91.

New Straits Times (NST). (2017, July 27). More than 1.7 million foreign workers in Malaysia; majority from Indonesia. Retrieved from https://www.nst.com.my/news/ nation/2017/07/261418/more17-million-foreign-workersmalaysia-majority-indonesia

Norhidayu, S., Yvonne, A. L., Farnza, A., Behnke, J. M., Lewis, J. W., \& Siti Nursheena, M. Z. (2016). Migrant workers in Malaysia: Current implications of sociodemographic and environmental characteristics in the transmission of intestinal parasitic infections. Journal of $\mathrm{Ne}$ glected Tropical Diseases, 10(11), 1-17.

Open Working Group on Labour Migration and Recruitment. (2017). Ethical recruitment, policy brief no. 5. Retrieved from http:// mfasia.org/migrantforumasia/wp -content/uploads/2017/01/5Policy-Brief-Support-for-EthicalRecruitment.pdf

Rahimah, A., \& Suriati, I. (2013). Working children and knowledge of right to education: A study of child labour in Sabah, Malaysia. Asian Social Sciences, 9(8), 23-33.

Rahman, M. M. (2012). Bangladesh labour migration to the Gulf States: Patterns of recruitment and the processes. Canadian Journal of Development Studies, 33(2), 214-230.

Spaan, E., \& Hillmann,F. (2013). Migration trajectories and the migration industry: Theoretical reflections and empirical examples from Asia. In Gammeltoft-Hansen and N. Nyberg Sorensen (eds.), The Migration Industry and the Commercialization of International Migration. 64-86. Abingdon: Routledge.

Spaan, E. \& Naerssen, T. N. (2018). Migration decision-making and migration industry in the IndonesiaMalaysia corridor. Journal of Ethnic and Migration Studies, 44(4), 680-695.

Varkkey, H. (2015). The human rights dimension in the revised RSPO principles and criteria. Malaysian Journal of International Relations, 3 (December), 153-158.

Wahab, Andika. (2019). Human rights anchored in business: Practice and challenges in the palm oil sector in Malaysia. Asian International Studies Review, 20(1).

Wall Street Journal. (2015, July 26). Palm oil migrant workers tell of abuses on Malaysian plantations. Retrieved from https:// www.wsj.com/articles/palm-oilmigrant-workers-tell-of-abuseson-malaysian-plantations1437933321

Wickramasekara, P. (2000). Asian labour migration: Issues and challenges in an era of globalization. ILO Asia -Pacific Regional Symposium for Trade Union Organizations on Migrant Workers, 6-8, December 1999, Kuala Lumpur, Malaysia. Retrieved from https:// www.ilo.org/asia/publications/ WCMS_160632/lang--en/ index.htm 